\title{
THE UTILIZATION OF ETHANOL BY DAIRY COWS
}

\author{
Olof A. Forsander. Martti Lampila and Bengt Westerling \\ Research Laboratories of the State Alcohol Monopoly (Alko), Helsinki \\ Agricultural Research Centre, Department of Animal Husbandry, Tikkurila \\ College of Veterinary Medicine, Helsinki
}

Received September 7, 1967

Experiments on the use of ethanol as an additive in the diet of ruminants have been performed for about 10 years. Some workers have found that ethanol has a positive effect on the weight gains of young steers (ANDERSON and RAPP 1955), some have found that it may increase the digestibility of the feed (KIRK et al. 1962) and may promote the utilization of urea for protein synthesis by the ruminal microflora (RAPP and ANDERSON 1956). Other workers have, however, failed to obtain such beneficial effects (Williams and Tribe 1957, Morris and HorTon 1959, Foot 1966).

In the rumen the cellulose consumed is broken down mainly to acetic acid, propionic acid and butyric acid which are absorbed in the portal system and metabolized and oxidized in the body. These organic acids, and particularly acetic acid, are one of the main substrates for the oxidation in various tissues of the body (ANNISON and LindSAY 1961). In all species studied, ethanol is oxidized in the liver to acetic acid, which is transported by the blood to the extrahepatic tissues and oxidized there. It can be assumed that the ethanol consumed by the ruminant also is oxidized to acetic acid, which in turn can be utilized by all kinds of tissues for oxidation.

The amount of ethanol given to the animals in the above mentioned experiments has usually been rather small and could only have played a minor role in the daily caloric intake of the animals. Information concerning the effect of nutritionally significant amounts of ethanol given to ruminants is scarce.

At the Agricultural Research Centre in Tikkurila, experiments have been carried out with the object of: 1) obtaining information on the rate of ethanol 
oxidation and the maximal amount of this compound combusted daily in the ruminant, and 2) studying the effect of an extended feeding of large amounts of ethanol on milk production, milk quality and behavior in general in dairy cows. The main purpose of the work is to study the possibilities of using ethanol as a true source of energy for dairy cows.

\section{Material and methods}

The work was performed on Ayrshire cows, 3 to 11 years old. They were all in good health and weighed from 485 to $555 \mathrm{~kg}$. Two of the cows were fitted with permanent rumen fistulas. These animals and one of the unfistulated cows, were not lactating. The work was carried out during the indoor season. The diet before and during the experiments consisted of hay, silage and concentrate mixture. Water or ethanol solution respectively was freely available. The ethanol used was of grade "B" of the Finnish State Alcohol Monopoly (Alko). This is a technical product made at the pulp mills. It contains 94 per cent $(\mathrm{w} / \mathrm{w})$ ethanol and, as impurities, traces of fusel alcohols and aldehydes.

The first part of the work concerning the oxidation rate of ethanol was carried out in two experiments. In the first experiment two cows each were given orally $320 \mathrm{~g}$ ethanol as a 25 per cent solution in one dose. In the second experiment four cows received each $640 \mathrm{~g}$ ethanol in the same manner. Blood samples for ethanol determination were taken at hourly intervals after the ethanol administration.

In the second part of the work, six cows, one of which was fistulated, received instead of drinking water a $1.37-2.04$ per $100 \mathrm{ml}$ alcoholic solution for a period of seven days. During two days preceding the experiment the normal water consumption of the test cows and the milk produced were measured. Throughout the experiment the liquid drunk was measured regularly 15 times every 24 hours.

Samples of milk and rumen fluid plus a series of blood samples were taken on the second and seventh days. The ethanol and fat content of the milk samples were determined. The flavour of the milk was tested organoleptically by four trained tasters. The ethanol content of the rumen fluid taken from two fistulated cows, one of which received the ethanol solution, was determined. The ethanol content, and on the seventh day also the glucose content, of the blood samples was determined.

Ethanol and glucose were determined by the enzymic methods recommended by Böhringer and Söhne (Mannheim, Germany). Blood ethanol values are given in parts per thousand $(\%, \mathrm{w} / \mathrm{v})$.

The milk fat was determined according to Gerber.

All the blood samples were taken alternately from the left and right jugular veins.

\section{Results and discussion.}

The blood ethanol concentrations of the cows during the oxidation rate experiments are given in Fig. 1. From the results it can be calculated (Widmark 1932) that on average the blood ethanol concentration decreased by $0.092 \%$ per hour 


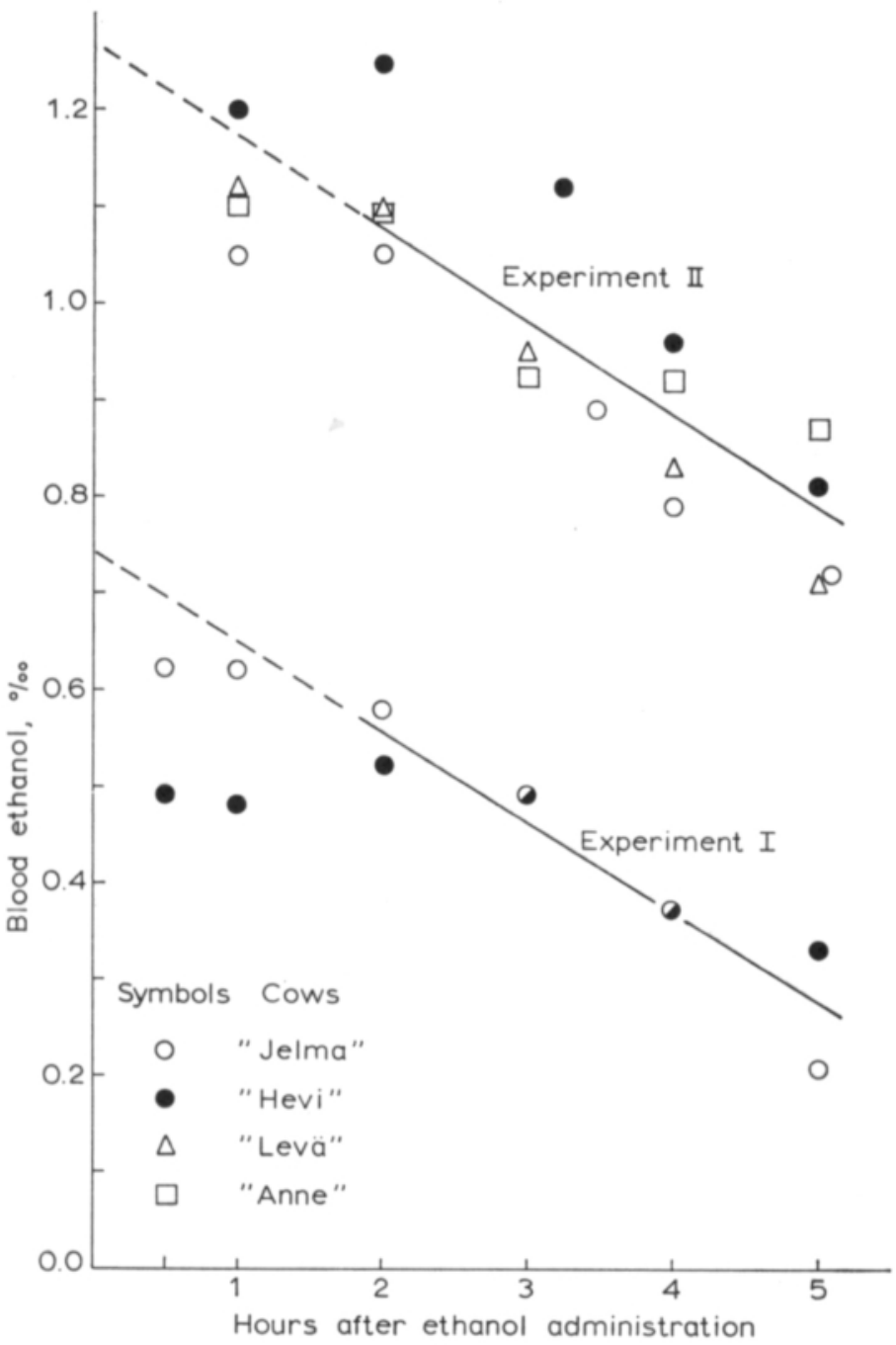

Fig. 1. Ethanol concentration of the blood (of cows) after a single dose of ethanol. Two cows received $320 \mathrm{~g}$ (Experiment 1) and four $640 \mathrm{~g}$ (Experiment 2) ethanol.

( $\beta 60$ value). The capacity for a day-long ethanol oxidation by the four cows receiving $620 \mathrm{~g}$ of ethanol is seen in Table 1 . The mean maximal ethanol oxidation was $1390 \mathrm{~g}$ per $500 \mathrm{~kg}$ body weight per day.

In earlier experiments where ethanol has been given to ruminants, the amounts administered usually have been rather small. The share of calories from the ethanol has therefore been low compared to the daily caloric intake. If an animal is drinking an amount of ethanol which equals the maximal daily oxidation capacity, the calories therein could play a rather large role in the nutritional economy of the animal. 
Table 1. The daily ethanol oxidation by four cows. The values given are calculated from the rate of ethanol elimination in the blood after the $640 \mathrm{~g}$ dose of ethanol had been given.

\begin{tabular}{cccc}
\hline Cow & $\begin{array}{c}\text { weight } \\
\text { kg }\end{array}$ & $\begin{array}{c}\text { kg oxidized } \\
\text { per 24 hrs }\end{array}$ & $\begin{array}{c}\text { kg oxidized per } \\
500 \mathrm{~kg} \text { in } \\
24 \mathrm{hrs}\end{array}$ \\
\hline "Jelma" & 514 & 1.330 & 1.290 \\
"Leväs & 485 & 1.540 & 1.590 \\
"Hevis & 493 & 1.490 & 1.510 \\
"Anne" & 555 & 0.830 & 0.750 \\
\hline
\end{tabular}

It can be calculated that a cow consuming $1 \mathrm{~kg}$ of ethanol would oxidize about $750 \mathrm{~g}$ of it, the rest being eliminated as such in the urine, the milk and the expired air. At least in man (Atwater and Benedict 1899) and in rat (GIllespie and Lucas 1958), the ethanol calories are utilized as readily as the calories in normal food. It can be assumed that the cow as well is capable of utilizing ethanol calories. This would mean that of the 9939 Calories contained in $1390 \mathrm{~g}$ ethanol, 7454 Calories would be metabolized. Assuming a metabolic loss of $30 \%$, this energy intake would satisfy $2 / 3$ of the maintenance requirement of a $500 \mathrm{~kg}$ cow.

In experiment 1 , the cows showed no detectable signs of intoxication while in experiment 2, all four animals appeared intoxicated to various degrees within $30-45$ minutes after the alcohol administration, remaining so for several hours.

The cow seems thus to be rather sensitive to the intoxicating effect of ethanol. While the rat is noticeably intoxicated when the blood ethanol concentration rises over $2 \%$, man shows signs of intoxication at a concentration half of this, and the cow when the blood value is somewhat below $1 \%$.

The cows used for the second part of the work consumed normally $60-70 \mathrm{l}$ of water per day and from this was calculated that if the water would contain 2.0 per cent of ethanol, the amount consumed daily would equal the oxidizing capacity of the animals. Ethanol would not then accumulate in the body to produce intoxication. The drinking water is, however, not consumed in small portions throughout the whole day, but in larger portions at certain times, especially during and after feeding. Therefore the amount of ethanol taken at a single time can sometimes be great enough to produce visible intoxication. This was once observed in one cow during the first day after which the ethanol concentration of the water was lowered to about 1.4 per cent. This concentration did not produce any signs of intoxication in the animals.

The amount of ethanol solution and the calculated amounts of ethanol consumed by the individual cows are shown in Table 2 .

The ethanol content of the blood and of the milk was followed during the second and the seventh day of the experiment. The results appear from Figs. 2 and 3. During the second day, the ethanol concentration of blood and milk was on the average distinctly higher than during the seventh day. This may depend on the possibility that the cows were capable of adapting themselves to metabolize ethanol 
Table 2. Daily ethanol consumption of individual cows during the experiment. The first day the drinking solution contained 2.04 per cent ethanol $(\mathrm{w} / \mathrm{v})$ and the days thereafter 1.37 per cent. The day period was from $5.00-15.00 \mathrm{hrs}$ and the night period from $15.00-5.00 \mathrm{hrs}$.

\begin{tabular}{|c|c|c|c|c|c|c|c|c|c|c|c|}
\hline \multirow[b]{2}{*}{ Cow } & \multicolumn{6}{|c|}{ Solution consumed, liter } & \multicolumn{5}{|c|}{ Solution consumed, liter } \\
\hline & Day & $\begin{array}{c}\text { during } \\
\text { day }\end{array}$ & $\begin{array}{l}\text { during } \\
\text { night }\end{array}$ & total & $\begin{array}{c}\text { Ethanol } \\
\text { kg }\end{array}$ & Cow & Day & $\begin{array}{c}\text { during } \\
\text { day }\end{array}$ & $\begin{array}{c}\text { during } \\
\text { night }\end{array}$ & total & $\begin{array}{c}\text { Ethanol } \\
\text { kg }\end{array}$ \\
\hline \multirow[t]{9}{*}{ "Levä" } & 1 & 30.5 & 34.0 & 64.5 & 1.316 & Kekri & 1 & 25.0 & 37.0 & 62.0 & 1.061 \\
\hline & 2 & 31.5 & 34.5 & 66.0 & .904 & & 2 & 29.0 & 23.0 & 52.0 & .712 \\
\hline & 3 & 30.5 & 34.5 & 65.0 & .891 & & 3 & 20.5 & 29.0 & 49.5 & .678 \\
\hline & 4 & 25.5 & 37.5 & 63.0 & .863 & & 4 & 30.5 & 33.5 & 64.0 & .877 \\
\hline & 5 & 30.0 & 40.0 & 70.0 & .959 & & 5 & 29.5 & 34.0 & 63.5 & .870 \\
\hline & 6 & 28.0 & 26.0 & 54.0 & .740 & & 6 & 29.5 & 25.5 & 55.0 & .754 \\
\hline & 7 & 27.5 & 31.5 & 59.0 & .808 & & 7 & 28.0 & 23.0 & 51.0 & .699 \\
\hline & Sum & 203.5 & 238.0 & 441.5 & 6.481 & & & 192.0 & 205.0 & 397.0 & 5.651 \\
\hline & Mean & 29.1 & 34.0 & 63.1 & .926 & & & 27.4 & 29.3 & 56.7 & .807 \\
\hline \multirow[t]{9}{*}{ "Hannis } & 1 & 22.5 & 36.5 & 59.0 & 1.204 & Jelma & 1 & 21.0 & 33.0 & 54.0 & 1.102 \\
\hline & 2 & 36.5 & 40.0 & 76.5 & 1.048 & & 2 & 26.5 & 26.0 & 52.5 & .719 \\
\hline & 3 & 24.0 & 38.0 & 62.0 & .849 & & 3 & 21.0 & 39.0 & 60.0 & .822 \\
\hline & 4 & 33.0 & 35.5 & 68.5 & .938 & & 4 & 31.0 & 35.5 & 66.5 & .911 \\
\hline & 5 & 32.0 & 36.5 & 68.5 & .938 & & 5 & 23.0 & 36.5 & 59.5 & .815 \\
\hline & 6 & 35.0 & 25.5 & 60.5 & .829 & & 6 & 24.0 & 19.0 & 43.0 & .589 \\
\hline & 7 & 31.5 & 30.0 & 61.5 & .843 & & 7 & 26.0 & 22.0 & 48.0 & .658 \\
\hline & Sum & 214.5 & 242.0 & 456.5 & 6.649 & & & 172.5 & 211.0 & 383.5 & 5.616 \\
\hline & Mean & 30.6 & 34.6 & 65.2 & .950 & & & 24.4 & 30.1 & 56.5 & .802 \\
\hline \multirow[t]{9}{*}{ 'Kukus } & 1 & 18.0 & 32.5 & 50.5 & 1.030 & "Irpula" & 1 & 5.0 & 19.5 & 24.5 & .500 \\
\hline & 2 & 34.0 & 32.5 & 66.5 & .911 & & 2 & 14.0 & 18.0 & 32.0 & .438 \\
\hline & 3 & 20.5 & 32.5 & 52.5 & .719 & & 3 & 18.5 & 16.0 & 34.5 & .473 \\
\hline & 4 & 31.0 & 32.0 & 63.0 & .863 & & 4 & 15.0 & 16.0 & 31.0 & .425 \\
\hline & 5 & 22.0 & 27.5 & 49.5 & .678 & & 5 & 12.0 & 16.0 & 28.0 & .384 \\
\hline & 6 & 31.5 & 20.5 & 52.0 & .712 & & 6 & 12.5 & 24.5 & 37.0 & .507 \\
\hline & 7 & 21.0 & 19.5 & 40.5 & .555 & & 7 & 15.5 & 15.5 & 31.0 & .425 \\
\hline & Sum & 178.0 & 197.0 & 374.5 & 5.468 & & & 92.5 & 125.5 & 218.0 & 3.152 \\
\hline & Mean & 25.4 & 28.1 & 53.5 & .781 & & & 13.2 & 17.9 & 31.1 & .450 \\
\hline
\end{tabular}

more efficiently or also to the fact that there were certain disturbances in the cowshed during the seventh day which lowered the water intake of the animals. The ethanol concentration of the milk was about the same as that of the blood which is in agreement with the observations that the alcohol consumed after the resorption period is in equilibrium with the water phase of all tissues in the body (EGGLETON 1940).

The milieu of the rumen is rather anaerobic and a part of the food there is reduced to ethanol (ANNIson et al. 1957). The bulk of the food is however, fermented 


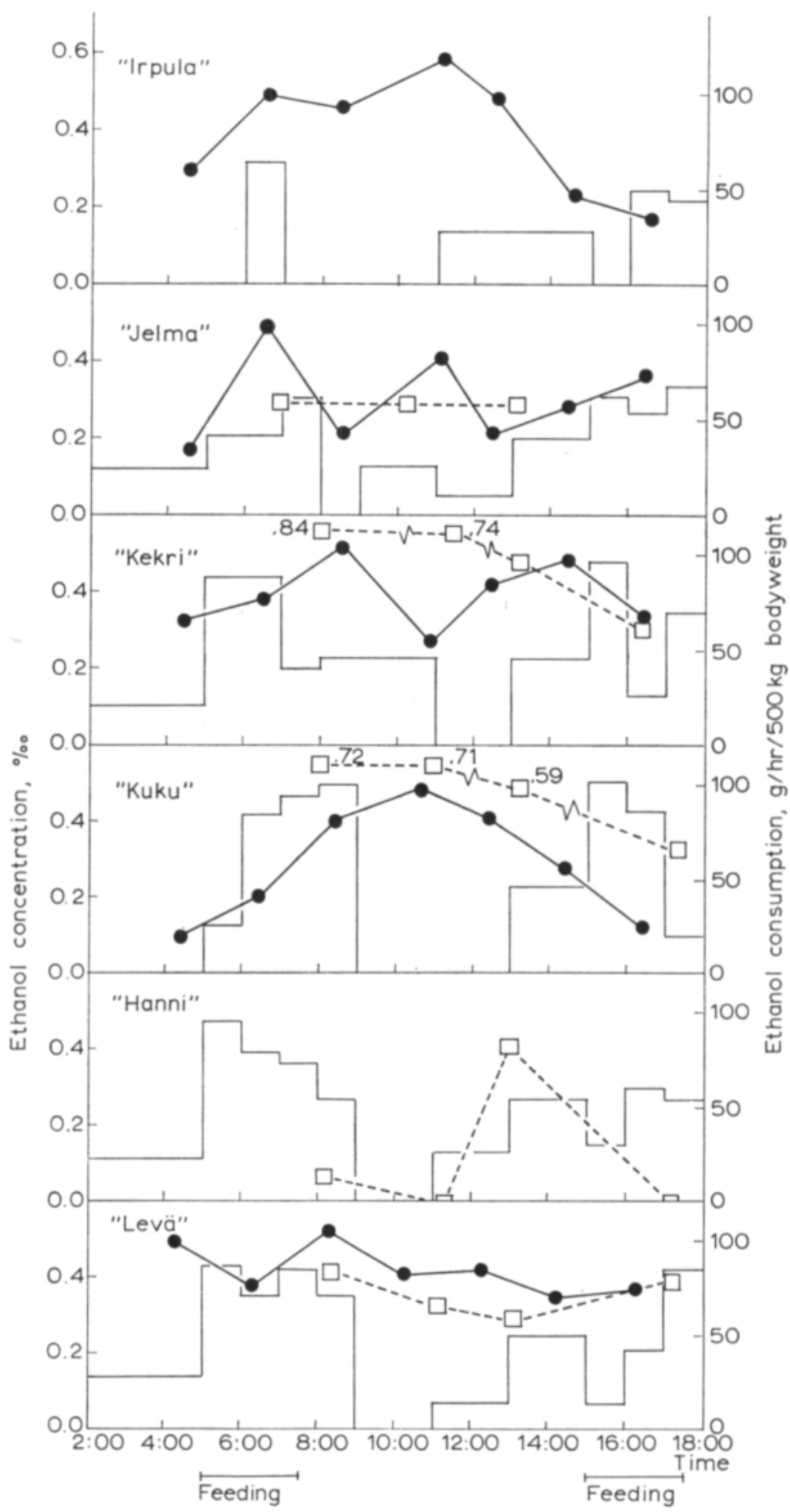

Fig. 2. Consumption of ethanol, and blood and milk ethanol concentrations of the cows during the second day on the 1.4 per cent ethanol-water solution. ethanol consumed; blood ethanol; $\square------\square$ milk ethanol. 


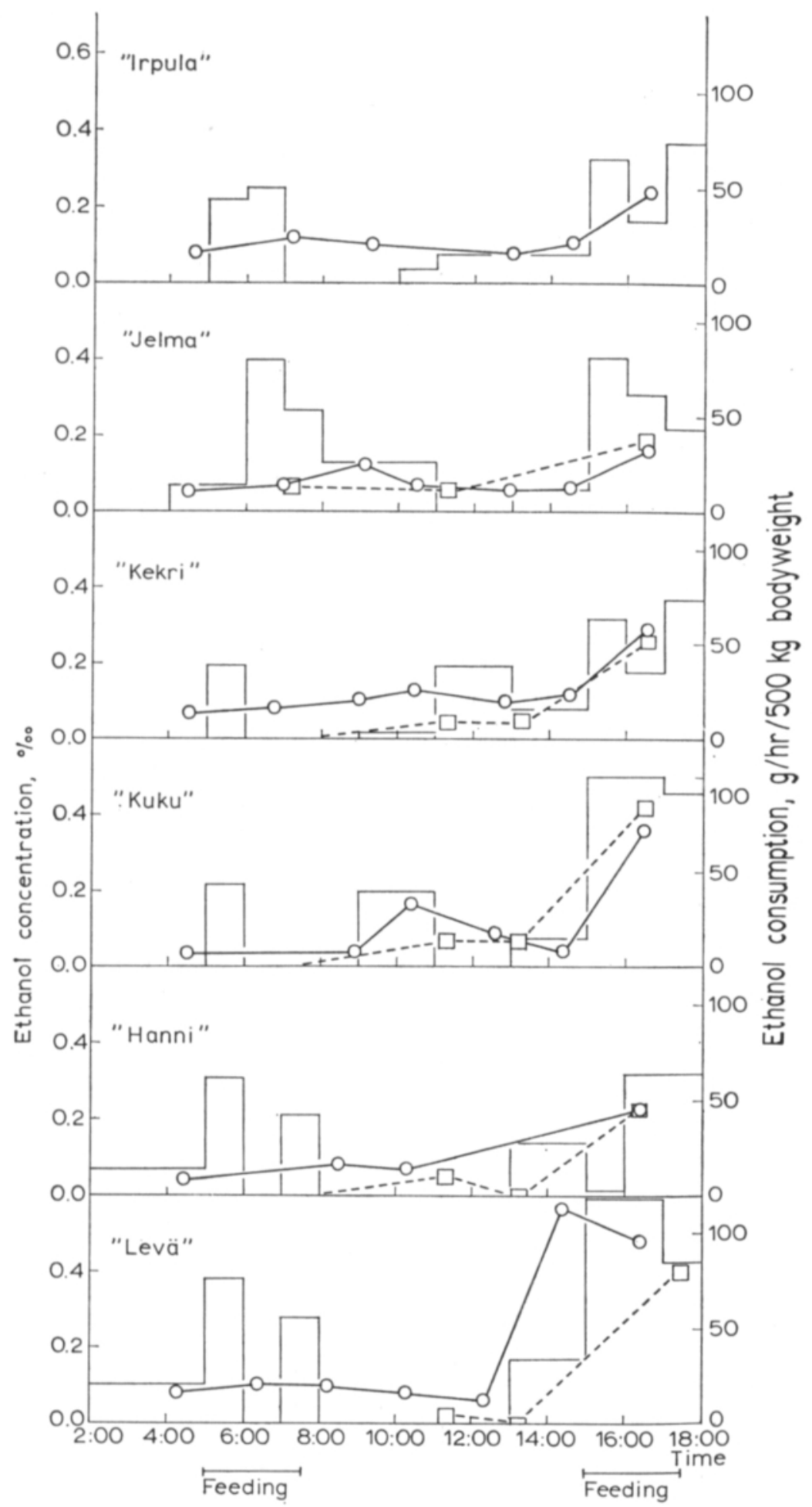

Fig. 3. Consumption of ethanol, and blood and milk ethanol concentrations of the cows during the seventh day on the 1.4 per cent ethanol-water solution. ethanol consumed; $\mathrm{O}-\mathrm{O}$ blood ethanol; $\square------\square$ milk ethanol. 
to low molecular organic acids. The ethanol concentration of ruminal contents of the cow receiving pure water stayed close to over $0.1 \%$, while the concentration in the cow drinking the $1.4 \%$ ethanol solution was considerably higher, rising to almost $0.4 \%$ (Fig. 4). The result of this part of the experiment shows further that the ethanol ingested is rapidly diluted with the rumen fluid and absorbed by the blood with which it is nearly in equilibrium.

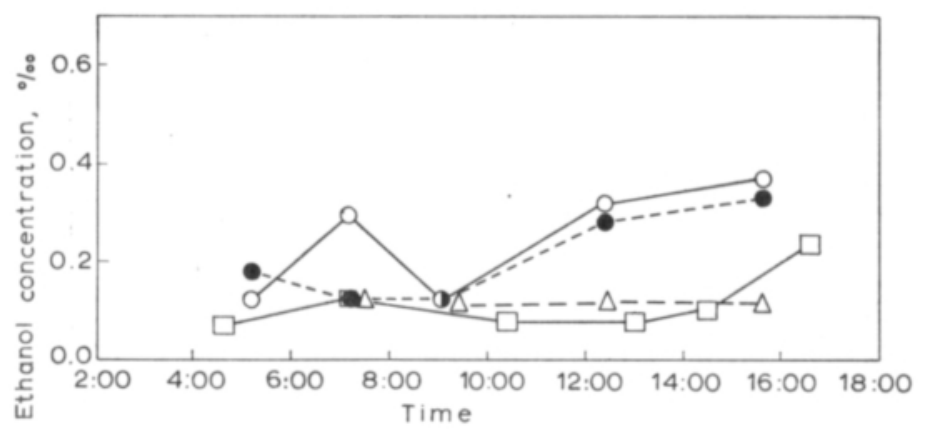

Fig. 4. The ethanol concentration of the rumen of one cow srpulas drinking 1.4 per cent ethanolwater solution and of one "Inaris drinking water. Blood ethanol concentration of srpulas is also given.

$\bigcirc-\bigcirc$ upper rumen; - - - - lower rumen; $\square-\square$ blood ethanol of srpulas.

$\Delta-\cdots \Delta$ upper and lower rumen of snaris.

Table 3. Daily milk production of individual cows during the experiment and the two preceding days $(0,00)$ and results of the two milk fat determinations.

\begin{tabular}{|c|c|c|c|c|c|c|c|c|c|c|}
\hline \multirow[b]{2}{*}{ Day } & \multicolumn{2}{|c|}{ ¿Levã. } & \multicolumn{2}{|c|}{ Hannis } & \multicolumn{2}{|c|}{ Kuku } & \multicolumn{2}{|c|}{ Kekri } & \multicolumn{2}{|c|}{ Jelma" } \\
\hline & $\begin{array}{c}\text { Milk } \\
\text { kg }\end{array}$ & $\begin{array}{c}\text { Fat } \\
\%\end{array}$ & $\begin{array}{c}\text { Milk } \\
\text { kg }\end{array}$ & $\begin{array}{c}\text { Fat } \\
\%\end{array}$ & $\begin{array}{c}\text { Milk } \\
\text { kg }\end{array}$ & $\begin{array}{c}\text { Fat } \\
\%\end{array}$ & $\begin{array}{c}\text { Milk } \\
\text { kg }\end{array}$ & $\begin{array}{c}\text { Fat } \\
\%\end{array}$ & $\begin{array}{c}\text { Milk } \\
\text { kg }\end{array}$ & $\begin{array}{c}\text { Fat } \\
\%\end{array}$ \\
\hline 00 & 22.9 & 4.2 & 21.5 & 4.8 & 19.5 & 4.8 & 18.3 & 4.3 & 17.1 & 4.7 \\
\hline 0 & 23.7 & & 22.2 & & 19.6 & & 17.8 & & 15.7 & \\
\hline 1 & 21.5 & & 18.4 & & 18.1 & & 16.0 & & 15.6 & \\
\hline 2 & 21.5 & & 19.9 & & 18.1 & & 17.6 & & 15.6 & \\
\hline 3 & 22.1 & & 21.2 & & 18.9 & & 16.1 & & 16.6 & \\
\hline 4 & 21.3 & & 21.6 & & 18.6 & & 17.0 & & 15.8 & \\
\hline 5 & 21.2 & & 20.9 & & 18.1 & & 18.5 & & 17.3 & \\
\hline 6 & 21.3 & & 21.9 & & 18.0 & & 17.4 & & 17.8 & \\
\hline 7 & 22.5 & 4.7 & 22.3 & 4.2 & 18.7 & 5.0 & 18.1 & 5.1 & 17.8 & 4.4 \\
\hline
\end{tabular}

The milk production of the animals and the fat content of the milk produced during the experiment are shown in Table 3. The drinking of ethanol solution instead of water seemed to have no lasting effect on the production level or the milk fat percentage of the cows. Intoxicating doses of ethanol have been shown to produce inhibition of the lactation in the rat (KIEssLing 1965). It can be assumed that the blood ethanol concentration in the cows drinking the 1.4 per cent solution never rose to a level where a pharmacological effect could have been produced. The slight 
decrease in production during the first days of the experiment is likely to depend on the cows adapting themselves to the new energy source. Also the disturbance produced by the sampling is indeed of importance.

Table 4. Results of the organoleptic milk quality tests. The numbers represent means of points given to samples of milk from experimental cows and mixed milk from the rest of the herd by four professional tasters. The test was accomplished as a oblindo test according to a quality scale from 0 to 5 points.

\begin{tabular}{|c|c|c|c|}
\hline No & Sample from & $\begin{array}{c}\text { Control milk } \\
\text { points }\end{array}$ & $\begin{array}{l}\text { Experiment } \\
\text { milk points }\end{array}$ \\
\hline 1 & mixed milk & 4.5 & \\
\hline 2 & "Levă" & & 0.5 \\
\hline 3 & mixed milk & 4.5 & \\
\hline 4 & mixed milk & 5.0 & \\
\hline 5 & Hannis & & 1.0 \\
\hline 6 & mixed milk & 4.3 & \\
\hline 7 & Kuku & & 2.0 \\
\hline 8 & mixed milk & 5.0 & \\
\hline 9 & Kekris & & 0 \\
\hline 10 & mixed milk & 3.8 & \\
\hline 11 & Jelma morning & & 2.9 \\
\hline 12 & Jelmas evening & & 4.5 \\
\hline 13 & „Levä" & & 0 \\
\hline 14 & LLevä & & 0.8 \\
\hline 15 & mixed milk & 2.5 & \\
\hline 16 & Hannis & & 0.8 \\
\hline 17 & mixed milk & 4.4 & \\
\hline 18 & Kuku» & & 0.3 \\
\hline 19 & mixed milk & 4.0 & \\
\hline 20 & Kekris & & 0.8 \\
\hline 21 & mixed milk & 4.3 & \\
\hline
\end{tabular}

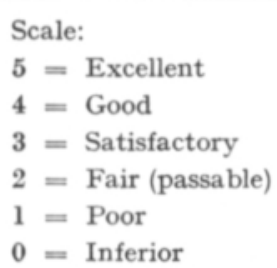

The experiment had, however, an unfavourable effect on the milk quality of the cows (Table 4). As judged by the four tasters, the flavour of the milk produced by the experimental cows during the experiment was definitely inferior to the milk produced by the other cows of the herd. It is well known that the flavour of milk is extremely sensitive to flavour compounds in the diet, and since the technical ethanol used in the experiment contained impurities with a specific aroma, it cannot be concluded to what extent the impairment was induced by the ethanol itself or by the impurities mentioned. LAMPILA and KYLÄ-SIUROLA (1967) have noticed that also relatively small doses of highly purified ethanol (Alko, Grade «A») may affect the flavour of the milk. 
During the experiment no negative effect on the physical condition of the cows could be seen. If alcohol is consumed in intoxicating doses by man (FORSANDER et al. 1958) or by some animals (BLEICHERT et al. 1964) a marked hypoglycemia is often observed. In the morning on the last day of the ethanol experiment blood samples were taken from the cows and analyzed for glucose (Table 5). The values

Table 5. Blood glucose values in the morning of the seventh day of administering ethanol solution.

\begin{tabular}{lc}
\hline Cow & Blood glucose mg \% \\
\hline "Levä" & 57.4 \\
"Hannis & 57.1 \\
"Kuku" & 49.4 \\
"Kekris & 46.3 \\
"Jelma" & 49.2 \\
"Irpula. & 55.9 \\
\hline
\end{tabular}

obtained are in accordance with values regarded normal in earlier tests on blood glucose in the herd. Even here the fact that the pharmacological state of intoxication was not produced in the cows presumably explains the discrepancy with observations in other animal species.

\section{$S u m m$ ary}

A preliminary study of the possibility of using large amounts of ethanol as an energy source for milking cows has been made.

During the whole of the experimental period the cows were stall fed. Maximum blood ethanol levels were found $1 / 2-2$ hours after dosing. Measurements of the rate of decrease of blood ethanol concentration, which is affected in part by elimination of ethanol in urine, milk and exhaled air, gave an apparent rate of oxidation in the animal organism (mean value for 4 cows) of 1.39 (range $0.75-1.59) \mathrm{kg}$ per $500 \mathrm{~kg}$ live weight per $24 \mathrm{hr}$.

During a 7-day experiment the cows' drinking water contained about $1.4 \%$ (w/v) ethanol. Their health did not appear to be affected adversely and blood glucose levels measured on the 7th day were normal. Milk yields decreased slightly at the beginning of the ethanol administration but then rose again during a period of a few days to pre-experiment levels.

Drinking water containing $2 \%$ ethanol caused clear intoxication in the cow which drank most (animal fell over).

Administration of ethanol in the drinking water gave rise to a distinct offflavour in the milk.

\section{REFERENCES}

ANDERson, P. C. \& RAPP, J. L. C. 1955. Available hydrogen for rumen microfloral synthesis of protein in ruminants. Feed Service Communique 1: No. 1. 
Annison, E. F., Hill, K. J. \& Lewis, D. 1957. Studies on the portal blood of sheep. Biochem. J. 66: $592-599$.

$--\&$ Lindsay, D. B. 1961. Acetate utilization in sheep. Biochem. J. 78: 777-785.

Atwater, W. O. \& Benedict, F. G. 1896. An experimental inquiry regarding the nutritive value of alcohol. Mem. Nat. Acad. Sci. 8: 235-397.

Bleicher, S. J., Freinkel, N., Byrne, J. J. \& Seifert, D. 1964. Effect of ethanol on plasma glucose and insulin in the fasted dog. Proc. Soc. Exp. Biol. Med. 115: 369-373.

Eggleton, M. G. 1940. Determination of the metabolic rate of alcohol. J. Physiol. 98: 228-238.

Foor, J. Z. 1966: The value of ethanol as a supplement to a diet of straw, urea and molasses for sheep. Austral. J. Exp. Agric. Animal Husbandry 6: 317-320.

Forsander, O., Vartia, K. O. \& Krusius, F-E. 1958. Experimentelle Studien über die biologische Wirkung von Alkohol. 1. Alkohol und Blutzucker. Ann. Med. Exp. Biol. Fenn. 36: 416-423.

Gillespie, R. J. G. \& LucAs, C. C. 1958. Metabolic availability of energy of ingested ethyl alcohol. Can. J. Biochem. Physiol. 36: 307-317.

Kiessling, K-H. 1965. Personal communication.

Kirk, W. G., Peacock, F. M. \& Davis, G. K. 1962. Utilizing bagasse in cattle fattening rations. Florida Agr. Exp. Sta. Bull. No. 641.

LAmpila, M. \& KYLÄ-SiUrola, A-L. 1967. Observationer över verkan av olika doser etylalkohol på mjölkens fetthalt och arom i ett kortvarigt försök. NJF-Kongressen $27-30$ juni 1967 . Fortrykk av foredrag. Seksjon V, Husdyrbruk: $230-234$.

Morris, E. B. \& Horton, O. H. 1959. Supplementation of cottonseed hulls with an alcohol-urea preparation. J. Dairy Sci. 42: 353-357.

RAPP, J. L. C. \& ANDERson, P. C. 1956. The roles of essential amino acids and available hydrogen in the feeding of urea to ruminants. Feed. Service Communique 2: No. 2.

Williams, N. M. \& Tribe, D. E. 1957. The feeding of urea to sheep. J. Agr. (Victoria) 55: 769-771.

WIDMARK, E. M. P. 1932. Die theoretischen Grundlagen und die praktische Verwendbarkeit der gerichtlichmedizinischen Alkoholbestimmung. Urban \& Schwarzenberg, Berlin-Wien.

S E L O T U S :

\section{ETANOLIN KÄYTTÖ KOSKEVIA KOKEITA LYPSYLEHMILLÄ}

Olof A. Forsander, Marti Lampila ja Bengt Westerling

Alkon Keskuslaboratorio, Helsinki. Maatalouden tutkimuskeskus, kotieläinhoidon osasto, Tikkurila. Eläinlääketieteellinen Korkeakoulu, Helsinki.

Selostetussa työssä oli runsaan etanoliannostuksen käyttömahdollisuus lypsylehmän energiantarpeen tyydyttämisessä alustavan selvityksen kohteena.

Lehmät olivat kokeen aikana sisäruokinnalla. Veren etanolipitoisuuden huippuarvot esiintyivät 1/2-2 tunnin kuluttua kerta-annostuksen jälkeen. Pitoisuuden alenemisesta laskettuna oli etanolin palamisnopeus elimistőssä neljällä lehmällä keskimäärin $1.39 \mathrm{~kg}$ per $500 \mathrm{~kg}$ elopainoa 24 tunnissa (vaihtelurajat $0.75-1.59 \mathrm{~kg}$ ). Poistuminen virtsan, maidon ja hengitysilman mukana on osaltaan vaikuttanut näihin tuloksiin.

Juomaveden korvaaminen n. 1.4-prosenttisella (w/v) etanoli-vesiliuoksella ei näyttänyt haittaavan lehmien hyvinvointia seitsemän vuorokautta kestäneenä koeaikana. Seitsemäntenä vuorokautena tehdyissä määrityksissä havaittiin veren glukoosiarvojen olevan normaalilla tasolla. Maitotuotoksissa oli alkoholin juomisen alkuvaiheessa havaittavissa lievä alenema, mutta tuotokset kohosivat muutamassa päivässä suunnilleen koetta edeltäneelle tasolle. Noin $2 \%$ etanolia sisältänyt juomavesi aiheutti eniten juoneelle lehmälle selvän humalatilan (eläin kaatui).

Alkoholin juonti aiheutti maitoon selvän sivumaun. 